\title{
Studies on fresh milt parameters and cellular changes during cryopreservation of spermatozoa of Deccan mahseer Tor khudree (Sykes, 1839)
}

\author{
RAVINDRAGOUDA PATIL*, WAZIR SINGH LAKRA, SHRINIVAS JAHAGEERDAR \\ GOPAL KRISHNA AND ASIM KUMAR PAL \\ Fish Genetics and Biotechnology Division, Central Institute of Fisheries Education, Versova, Mumbai - 400061 \\ Maharashtra, India \\ "Fisheries Research and Information Center, Karnataka Veterinary, Animal and Fisheries Sciences University \\ Hessaraghatta, Bengaluru - 585 401, Karnataka, India \\ e-mail: ravi.patil30@gmail.com
}

\begin{abstract}
Studies on the physico-chemical characteristics of seminal plasma, along with ultrastructure and mitochondrial activity of fresh spermatozoa of the endangered Deccan mahseer Tor khudree were undertaken. The ultrastructure and mitochondrial activity of fresh spermatozoa were compared with those of cryopreserved-thawed spermatozoa to understand the nature and extent of cryo-damage. Physico-chemical analyses of fresh milt revealed sperm density of $3.93 \pm 0.11 \times 10^{7}$ spermatozoa ml $^{-1}$, spermatocrit value of $67.08 \pm 1.22 \%$, higher $\mathrm{K}^{+}$concentration of $13.16 \pm 0.121 \mathrm{mg} \mathrm{l}^{-1}$, total reducing sugar and total protein concentration of $47.31 \pm 0.82$ and $19.60 \pm 0.66 \mathrm{mg} 100 \mathrm{ml}^{-1}$ respectively. Ultrastructure of the fresh spermatozoa by both scanning (SEM) and transmission electron microscopy (TEM) revealed the spherical head without any acrosomal complex, small mid piece with mitochondria and a long tail. Cross section of tail by TEM revealed typical $9+2$ doublet arrangement of the axoneme. Head measured $1.86 \pm 0.006 \mu$ in dia with a mid-piece length of $0.53 \pm 0.012 \mu$ and tail length of $33.53 \pm 0.220 \mu$. Ultrastructural damages to the spermatozoa following cryopreservation included, loosening of chromatin and disruption of the cytoplasmic membrane as compared to that of fresh spermatozoa. Nitroblue tetrazolium (NBT) assay revealed low levels of activity of the enzymes of the mitochondrial complex in cryopreserved-thawed spermatozoa when compared to fresh spermatozoa indicating damage to the functional integrity of the enzymes of the mitochondrial enzyme complex.
\end{abstract}

Keywords: Cryopreservation, NBT assay, Physico-chemical characteristics, Spermatozoa, Tor khudree, Ultrastructure

\section{Introduction}

Physico-chemical characteristics of fish milt determine the fertilisation ability of spermatozoa (Rurangwa et al., 2004). Fish seminal plasma contains various organic and inorganic components which support the viability of spermatozoa (Hajirezaee et al., 2010). Hence, biochemical analysis of seminal plasma plays a significant role in the assessment of milt quality (Billard et al., 1995), which has applications related to artificial fertilisation and sperm preservation (Billard, 1978). Also, studies on the ultrastructure of fish spermatozoa are very much useful in understanding the phylogenetic relationships among different species (Jamieson, 1991) and they also help in comprehending damages following cryopreservation (Calvi et al., 1994; Lahnsteiner et al., 1996). Deccan mahseer, Tor khudree belonging to the family Cyprinidae, once formed a major fishery from the rivers and streams of Western Ghats and today, it is enlisted as an endangered species (Ogale, 1994; Basavaraja and
Keshavanath, 2000; Dahanukar et al., 2004). Attempts for its ex situ conservation using cryopreservation of spermatozoa have been made (Basavaraja et al., 2002; Patil and Lakra, 2005). For efficient mass production of T. khudree fingerlings for ranching purposes and also for development of efficient cryopreservation methodology, it is necessary to study the physico-chemical characteristics of seminal plasma. The present study was undertaken with the objectives of investigating the physico-chemical characteristics of seminal plasma as well as for studying the ultrastructure and mitochondrial activity of fresh spermatozoa in comparison with that of cryopreservedthawed spermatozoa to understand the nature and extent of cryo-damage.

\section{Materials and methods}

The present study was undertaken in the mahseer farm and hatchery complex of the Tata Power Company, Lonavala, Maharashtra State, bordering Sahyadri range of the Western Ghats. 
Sperm density, spermatocrit value and motility percentage

Mature males of $T$. khudree caught by gillnetting and in oozing condition were hand stripped. Milt samples not contaminated with water, faecal matter or blood were collected from individual males in separate clean, dry, sterile vials and stored in ice soon after collection. Density of spermatozoa in fresh milt of individual males was estimated, with improved Neubauer Haemocytometer following the method of Ax et al. (2000). Method of Rakitin et al. (1999) was followed for the estimation of Spermatocrit value. The spermatocrit value of fresh milt of individual males was estimated. For estimation of motility percentage of spermatozoa of individual males, method of Billard et al. (1995) was followed. Modified BWW (Ravinder et al., 1997) extender was used for milt dilution.

\section{Elemental composition of seminal plasma}

$\mathrm{Na}^{+}, \mathrm{K}^{+}, \mathrm{Ca}^{2+}, \mathrm{Mg}^{2+}$ and $\mathrm{Zn}^{2+}$ in the seminal plasma were estimated as per Gopalakrishnan et al. (1998) using Atomic Absorption Spectrophotometer (AAS) (Electronics Corporation of India Ltd. Model No. AAS 4129). Absorbance was measured at $589.0 \mathrm{~nm}$ for $\mathrm{Na}$, $766.50 \mathrm{~nm}$ for $\mathrm{K}^{+}, 422.70 \mathrm{~nm}$ for $\mathrm{Ca}^{2+}, 285.20 \mathrm{~nm}$ for $\mathrm{Mg}^{2+}$ and $213.90 \mathrm{~nm}$ for $\mathrm{Zn}^{2+}$. Samples were run in triplicates and $10 \%$ TCA was used as blank.

\section{Total reducing sugars and total proteins in seminal plasma}

Total reducing sugars in the pooled, fresh seminal plasma was estimated as per the modified method of Nelson and Somogyi (1945) and total proteins were estimated following Gopalakrishnan et al. (1998). The samples were run in triplicates and physiological saline was used as blank.

\section{Cryopreservation of spermatozoa}

Modified BWW extender and a combination of $9 \%$ dimethyl sulfoxide (DMSO) and $11 \%$ glycerol as cryoprotectant were used (Patil and Lakra, 2005). Only milt samples with more than $70 \%$ motile spermatozoa were subjected to cryopreservation (Lahnsteiner et al., 1997). The cryopreserved milt was subjected to fertilisation trials after a storage period of 30 days in $\mathrm{LN}_{2}$.

\section{Ultrastructure studies}

Scanning electron microscopic (SEM) studies were performed following the protocol of Ghadially (1986) using a Philips SEM Model Number L30 at ICAR-Central Institute for Research on Cotton Technology, Matunga, Mumbai. Morphometric parameters of fresh spermatozoa viz., head diameter, length and width of mid-piece and length and width of the tail were measured randomly for 100 spermatozoa. Transmission electron microscopy (TEM) studies were undertaken as per Ghadially (1986) in a Jeol-TEM Model no. Jem-1010 at Jaslok Hospital and Research Center, Pedder Road, Mumbai. Percentage of damaged spermatozoa was estimated randomly for 100 spermatozoa and fresh milt was used as control.

\section{Sperm mitochondrial activity Iidex (SMAI)}

Physiological changes in the cryopreserved-thawed spermatozoa were evaluated using sperm mitochindrial activity index (SMAI) by nitroblue tetrazolium (NBT) assay following the modified method of Gopalakrishnan et al. (1991) and Stasiack and Baumann (1996). The activity of the mitochondrial enzyme system was measured in terms of NBT reduction. The absorbance was measured at $620 \mathrm{~nm}$ using ELISA reader (Lab Systems Multiskan MS) with the help of "Genesis" software version 3.03.

\section{Statistical analysis}

Normality of the data was tested by Box-Plot method. Wherever needed, arcsine and logarithmic (to the base 10) transformations were carried out. Analysis of variance was performed between the mean values of different treatments at 5\% level. All the statistical analyses were performed using SAS Analyst Package (Version 8.2).

\section{Results and discussion}

Average sperm density of fresh milt from twelve males was estimated as $3.93 \pm 0.11 \times 10^{7}$ spermatozoa $\mathrm{ml}^{-1}$ (Table 1). However, a lower sperm density of $7.45 \times 10^{6}$ spermatozoa $\mathrm{ml}^{-1}$ for $T$. khudree was reported by Basavaraja et al. (2002). Gupta and Rath (1993) reported sperm densities of 2.0 to $2.5 \times 10^{7}, 3.0$ to $3.25 \times 10^{7}$ and 2.0 to $2.5 \times 10^{7}$ cells ml-1 for other cyprinid fish like catla (Catla catla), rohu (Labeo rohita) and mrigal (Cirrhina mrigala) respectively. Average spermatocrit value of fresh milt from twelve males was estimated to be $67.08 \pm 1.22$ (Table 1). Gupta and Rath (1993) recorded spermatocrit values ranging from $65-75,75-85$ and $65-75 \%$ for catla, rohu and mrigal respectively. On the contrary, a very low spermatocrit value of $11.5 \%$ was reported by Gasco et al. (1999) in rainbow trout (Oncorhynchus mykiss), which is also a cold water species. The differences in the findings by different researchers with respect to the sperm density and spermatocrit values may be due to differences in feeding conditions, husbandry procedures, age, environmental factors, spawning time or dilution ratio (Izquierdo et al., 2001; Aliniya et. al., 2013). It was observed in the present study that only nine males exhibited more than $70 \%$ motility and the average motility percentage of spermatozoa from the nine males was $95.01 \pm 0.85$ (Table 1). The present findings are in agreement with the observations of Basavaraja et al. (2002) who reported $95-100 \%$ motility of the spermatozoa from fresh milt of T. khudree. 
Table 1. Density, spermatocrit value and motility $\%$ of spermatozoa in fresh milt of $T$. khudree

\begin{tabular}{lll}
\hline $\begin{array}{l}\text { Sperm density } \\
\left(\mathrm{x} 10^{7} \text { spermatozoa } \mathrm{ml}^{-1}\right) \\
(\text { Mean } \pm \mathrm{SE})\end{array}$ & $\begin{array}{l}\text { \% Spermatocrit } \\
(\text { Mean } \pm \mathrm{SE})\end{array}$ & $\begin{array}{l}\% \text { Motile spermatozoa } \\
(\text { Mean } \pm \mathrm{SE})\end{array}$ \\
\hline $3.93 \pm 0.11$ & $67.08 \pm 1.22$ & $\begin{array}{l}95.01 \pm 0.85 \\
\text { (only from } 9 \text { males } \\
\text { with } \geq 70 \% \text { motility })\end{array}$ \\
& &
\end{tabular}

In the present study, it was found that the concentration of $\mathrm{K}^{+}$in the serminal plasma was higher (13.16 $\pm 0.121 \mathrm{mg} \mathrm{l}^{-1}$ ) when compared to that of $\mathrm{Na}^{+}, \mathrm{Ca}^{2+}$, $\mathrm{Mg}^{2+}$ and $\mathrm{Zn}^{2+}$ (Table 2). This explains the fact that the spermatozoa remain non-motile in the seminal plasma as high levels of potassium are found to inhibit sperm motility (Baynes et al., 1981). Similar observations were made by Plouidy and Billard (1982) that the concentration of $\mathrm{K}^{+}$was higher than the other elements in the seminal plasma of common carp.

Higher concentrations of total reducing sugars at levels of $47.31 \pm 0.82 \mathrm{mg} 100 \mathrm{ml}^{-1}$ in the seminal plasma were observed in the present study (Table 2). However, Lahnsteiner et al. (1994) reported lower concentration of total reducing sugars (glucose, fructose, galactose and xylose) in the seminal plasma of cyprinid fishes varying from 11.06 to $24.75 \mathrm{mg} 100 \mathrm{ml}^{-1}$. In some fish species, total reducing sugars in the seminal plasma do not play any role in providing energy for sperm locomotion and the ATP required for motility seems to be pre-accumulated in the spermatozoa (Billard et al., 1995). However, Gardiner (1978) reported that in some fish species, sperm motility remains longer, when extracellular source of glucose was provided and this indicates the ability of the spermatozoa to utilise energy-substrates in the seminal plasma. In the present investigation, it was found that the concentration of total proteins in seminal plasma was $19.60 \pm 0.66 \mathrm{mg} 100 \mathrm{ml}^{-1}$ (Table 3). Kruger et al. (1984) reported very low concentration of total proteins in the seminal plasma of common carp (0.04 to $0.38 \mathrm{mg} 100 \mathrm{ml}^{-1}$ ) and tilapia $\left(0.00\right.$ to $\left.0.06 \mathrm{mg} 100 \mathrm{ml}^{-1}\right)$. However, the

Table 2. Biochemical composition of the seminal plasma of fresh milt of T. khudree

\begin{tabular}{|c|c|}
\hline Chemical constituent & $\begin{array}{l}\text { Concentration } \\
(\text { Mean } \pm \text { SE })\end{array}$ \\
\hline \multicolumn{2}{|l|}{ Elements } \\
\hline Sodium $\left(\mathrm{mg} \mathrm{l}^{-1}\right)$ & $6.82 \pm 0.016$ \\
\hline Potassium $\left(\mathrm{mg} \mathrm{l}^{-1}\right)$ & $13.16 \pm 0.121$ \\
\hline Calcium $\left(\mathrm{mg} \mathrm{l}^{-1}\right)$ & $0.950 \pm 0.010$ \\
\hline Magnesium ( $\left.\mathrm{mg} \mathrm{l}^{-1}\right)$ & $0.275 \pm 0.004$ \\
\hline Zinc $\left(\mathrm{mg} \mathrm{l}^{-1}\right)$ & $0.018 \pm 0.004$ \\
\hline Total reducing sugars $\left(\mathrm{mg} 100 \mathrm{ml}^{-1}\right)$ & $47.31 \pm 0.82$ \\
\hline Total proteins $\left(\mathrm{mg} 100 \mathrm{ml}^{-1}\right)$ & $19.60 \pm 0.66$ \\
\hline
\end{tabular}

findings of the present study are similar to that of Lahnsteiner et al. (1994) who observed that the total protein content in the seminal plasma of cyprinid fishes

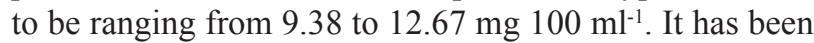
reported that the protein content in the seminal plasma varies from species to species (Lahnsteiner et al., 1994). Proteins play important role by protecting the spermatozoa by acting as buffers in the fish seminal plasma and help in maintaining the osmotic pressure (Kruger et al., 1984).

Table 3. Morphometric characteristics $(M e a n \pm S E)$ of fresh spermatozoa of T. khudree as revealed by SEM

\begin{tabular}{llllll}
\hline \multirow{2}{*}{$\begin{array}{l}\text { Head diameter } \\
(\mu \mathrm{m})\end{array}$} & \multicolumn{2}{c}{ Mid-piece } & & \multicolumn{2}{c}{ Tail } \\
\cline { 2 - 3 } \cline { 5 - 6 } & Length $(\mu \mathrm{m})$ & Width $(\mu \mathrm{m})$ & & Length $(\mu \mathrm{m})$ & Width $(\mu \mathrm{m})$ \\
\hline $1.86 \pm 0.006^{\mathrm{a}}$ & $0.53 \pm 0.012^{\mathrm{a}}$ & $0.60 \pm 0.004^{\mathrm{a}}$ & & $33.53 \pm 0.220^{\mathrm{a}}$ & $0.31 \pm 0.005^{\mathrm{a}}$ \\
\hline
\end{tabular}

*Values with different superscripts are significantly different

Scanning electron microscopy (SEM) investigations in cryopreserved-thawed spermatozoa, revealed several morphological deformities which included, winding of the tail, loss of tail, shrunken mid-piece, appearance of verrucosities on the surface of sperm head and severe roughening of the surface of the head (Fig. 1) when compared to that of fresh spermatozoa which revealed spherical head, small mid-piece, a long tail (Fig. 2) with a head diameter of $1.86 \pm 0.04 \mu$ and a tail length of $33.53 \pm 1.56 \mu$ (Table 4). Similar ultrastructural changes which included, disruption of plasma membrane, loss or winding of tail and appearance of verrucosities were reported by several researchers in SEM studies of cryopreserved-thawed/frozen-thawed spermatozoa of carps (Saad et al., 1988; Wei-xin and Ren-Liang, 1991).

Transmission electron microscopy (TEM) studies on the cryopreserved-thawed spermatozoa revealed amoeboid, triangular or irregular shapes, loosening or

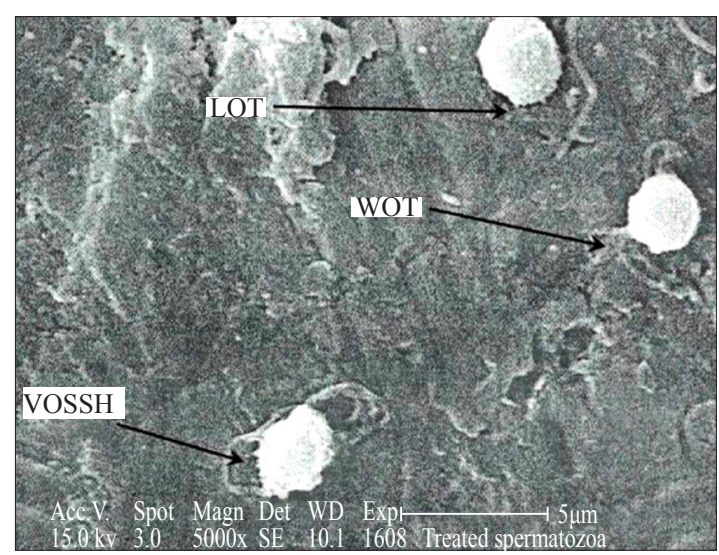

Fig. 1. Scanning electron micrograph of cryopreserved-thawed spermatozoa of T. khudree (x 2,500). LOT - loss of tail; WOT - Winding of tail; VOSSH - Verrucosities on the surface of sperm head 


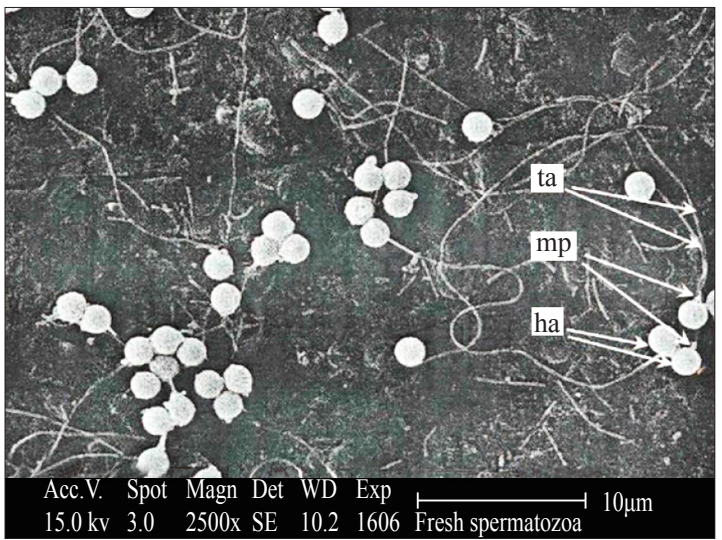

Fig. 2. Scanning electron micrograph of fresh spermatozoa of Tor khudree (x 2,500). ha - head; mp - mid piece; ta - tail

Table 4. Percentage of damaged spermatozoa in cryopreservedthawed milt of $T$. khudree as revealed by TEM

\begin{tabular}{ll}
\hline Milt sample & $\begin{array}{l}\% \text { of damaged } \\
\text { spermatozoa (Mean } \pm \text { SE) }\end{array}$ \\
\hline Cryopreserved-thawed milt & $62.88 \pm 1.53^{\mathrm{a}}$ \\
Fresh milt (Control) & $2.17 \pm 0.12^{\mathrm{b}}$ \\
\hline
\end{tabular}

"The values with different superscripts are significantly different

spillage of chromatin material and disruption of the cytoplasmic membrane (Fig. 3, 4) when compared to that of fresh spermatozoa which revealed a spherical head, smaller mid piece, two tiny cytoplasmic extensions on either side of the tail containing mitochondria, posterior end of head with a basal plate and cross section of the tail with typical $9+2$ arrangement of tail fibers (Fig. $5,6,7$ ) which play an important role in the beating of the tail that leads to the movement of the spermatozoa.

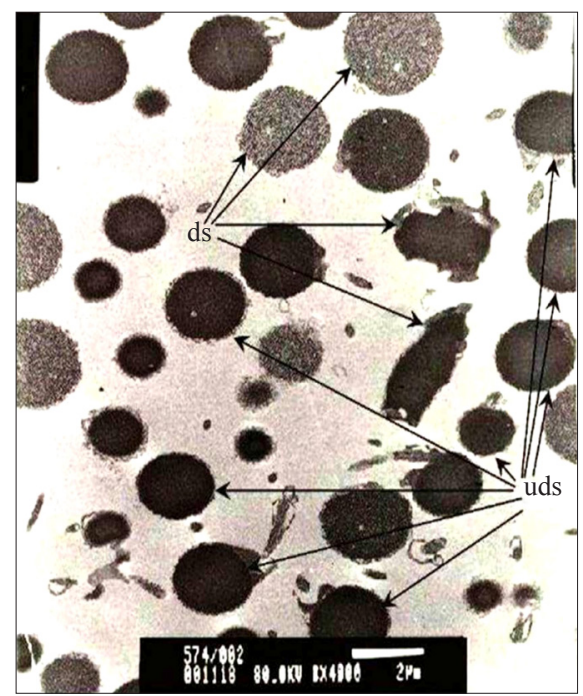

Fig. 3. Transmission electron micrograph showing damaged and intact spermatozoa during thawing ( $x$ 4,000). uds - undamaged spermatozoa; ds - damaged spermatozoa

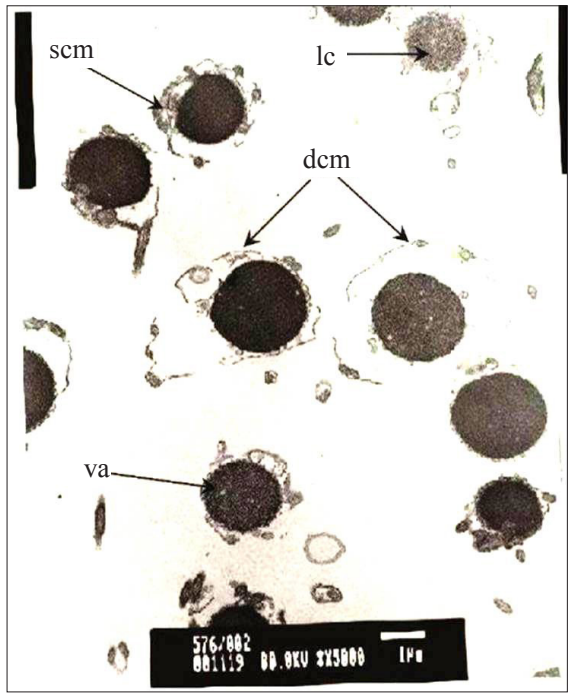

Fig. 4. Transmission electron micrograph showing the damage caused to the spermatozoa of T. khudree due to thawing $(x$ 5,000). va - vacuolisation; lc - loosening of chromatin; $\mathrm{dcm}$ - disrupted cytoplasmic membrane; scm - spilled chromatin material

Similar ultrastructural damages to the spermatozoa of common carp were recorded by several workers which included detachment of plasma membrane, loss of the central doublet, vacuolisation of nucleus and loosening of the chromatin of spermatozoa of common carp due to cryopreservation-thawing or freezing-thawing cycles (Saad et al., 1988; Drokin et al., 2003). Similar findings with a spherical head, smaller mid-piece and the typical $9+2$ arrangement of tail fibres in fresh spermatozoa were reported in case of Morone saxatilis (He and Woods III, 2004)

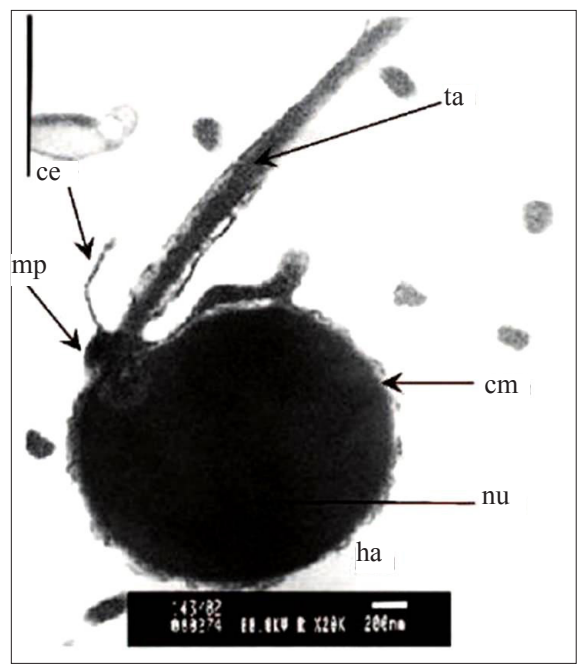

Fig. 5. Transmission electron micrograph of fresh spermatozoa of T. khudree (x 20,000). ha-head; mp-mid piece; ta-tail; nu-nucleus; cm-cytoplasmicmembrane; ce-cytoplasmic extension 


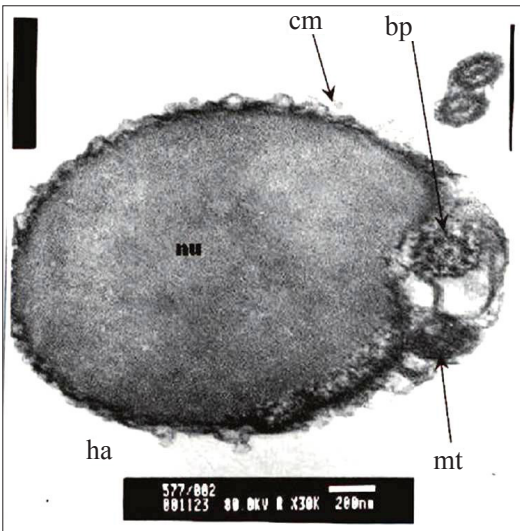

Fig. 6. TEM image of fresh spermatozoa of T. khudree (x 30,000). ha - head; nu - nucleus; cm - cytoplasmic membrane; bp - basal plate; $\mathrm{mt}$ - mitochondria

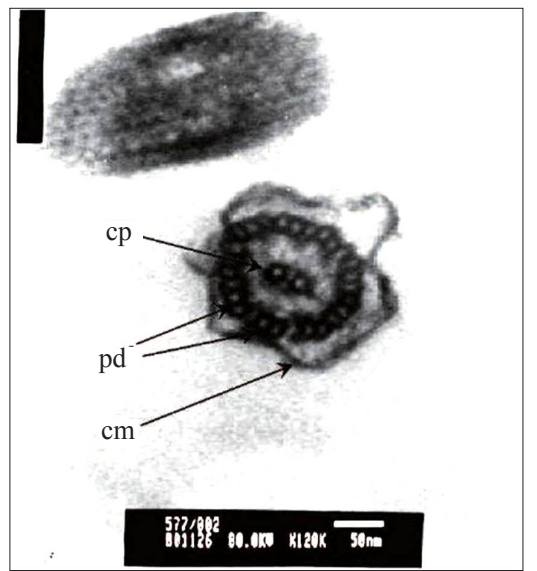

Fig. 7. TEM image of fresh spermatozoa of T. khudree showing cross section of the tail (x 1,20,000). Pd - peripheral doublets; $\mathrm{cp}$ - central pair; $\mathrm{cm}$ - cytoplasmic membrane

and Sander lucioperca (Kristian et al., 2014). In the present TEM studies, percentage of damaged spermatozoa after the cryopreservation-thawing cycle was estimated to be $62.88 \pm 1.53$ (Table 5). Results of the present study are in agreement with those reported by Lahnsteiner et al. (1992) who observed 40 - 50\% damaged spermatozoa after cryopreservation-thawing cycle in various fish species.

NBT assay, widely used for assessing SMAI which is considered as the indicator of functional integrity of mitochondria of human spermatozoa (Gopalakrishnan et al., 1991; Bergstrom et al., 2013), was for the first time

Table 5. Absorbance (OD) values of cryopreserved-thawed spermatozoa of $T$. khudree during NBT assay

\begin{tabular}{ll}
\hline Milt sample & Absorbance (Mean \pm SE) \\
\hline Cryopreserved-thawed milt & $0.087 \pm 0.002^{\mathrm{b}}$ \\
Fresh milt (Control) & $0.38 \pm 0.008^{\mathrm{a}}$
\end{tabular}

"Values with different superscripts are significantly different successfully applied to fish spermatozoa in the present study. The absorbance values for cryopreserved-thawed spermatozoa were significantly lower than that of fresh spermatozoa in the present study $(p<0.05)$ which give clear indication that cryopreservation-thawing cycle causes severe damage to the structural and functional integrity of enzymes of the mitochondrial-enzyme complex, which is responsible for the generation of ATP required for motility of the spermatozoa. Based on the results of the present study, it is suggested that better cryopreservation protocols need to be developed aiming at significant reduction in damages due to cryopreservation-thaw injury in spermatozoa of T. khudree and fish spermatozoa in general. Besides results of the physico-chemical parameters of serminal plasma from the present study indicate scope for formulating better extenders for cryopreservation of spermatozoa of T. khudree.

\section{Acknowledgements}

The financial assistance received from Indian Council of Agricultural Research, New Delhi for the present work is gratefully acknowledged. We thank the Director, ICAR-Central Institute of Fisheries Education, Mumbai and The Environmental Officer, Tata Power Company, Lonavala for providing lab and farm facilities.

\section{References}

Aliniya, M., Khara, H., Noveiri, S. B. and Dadras, H. 2013 Influence of age of common carp (Cyprinus carpio) broodstock on reproductive traits and fertilization. Turk. J. Fish. Aquat. Sci., 13: 19-25.

Ax, R. L., Dally, M., Didion, B. A., Lenz, R. W., Love, C. C., Varner, D. D., Hafez, B. and Bellin, M. E. 2000. Semen evaluation. In: Hafez, E. S. E. and Hafez, B. (Eds.), Reproduction in farm animals. Lippincott Williams and Wilkins Publishers, New York, p. 365-375.

Basavaraja, N. and Keshavanath, P. 2000. Conservation and management of fish genetic resources in Karnataka. In: Ponniah, A. G. and Gopalakrishnan, A. (Eds.), Endemic fish diversity of Western Ghats, NBFGR-NATP Publication, Lucknow, p. 152-154.

Basavaraja, N., Hegde, S. N., Akash, N. and Udupa, K. S. 2002. The fertility of cryopreserved Deccan mahseer, Tor khudree (Sykes) spermatozoa. Asian Fish. Sci., 15: 193-202.

Baynes, S. M., Scott, A. P. and Dawson, A. P. 1981. Rainbow trout, Salmo gairdneri (Richardson), spermatozoa: effects of cations and $\mathrm{pH}$ on motility. J. Fish Biol., 19: 259-267.

Bergstrom, B. and Jarkman, S. 2013. Correlation between sperm oxidative stress and sperm DNA damage in subfertile men. Masters thesis Submitted to Lund University, Sweden, $34 \mathrm{pp}$. 
Billard, R. 1978. Changes in structure and fertilizing ability of marine and freshwater fish spermatozoa diluted in media of various salinities. Aquaculture, 14: 187-198.

Billard, R., Cosson, J., Crim, L. W. and Suquet, M. 1995. Sperm physiology and quality. In: Bromage, N. R. and Roberts, R. J. (Eds.), Broodstock management and egg and larval quality. Blackwell Science Publishers, Oxford, p. 25-52.

Billard, R., Cosson, J., Perchec, G. and Linhart, O. 1995. Biology of sperm and artificial reproduction in carp. Aquaculture, 129: $95-112$.

Calvi, L. S., Zoccarato, I., Gasco, L. and Andrione, A. 1994. Effect of trehalose and/or albumin addition and methanol concentration on motility of cryopreserved carp semen (Cyprinus carpio L.). Revista Italiana Acquacoltura, 29: 45-51.

Dahanukar, N., Raut, R and Bhat, A. 2004. Distribution, endemism and threat status of freshwater fishes in the Western Ghats of India. J. Biogeogr., 31: 123-136.

Drokin, S. I., Stein, H. and Govorukha, T. P. 2003. Ultrastructure of carp, Cyprinus carpio spermatozoa after cooling, dilution and freeze-thawing. Cryo-Lett., 24: 49-56.

Gardiner, D. M. 1978. Utilisation of extracellular glucose by spermatozoa of two viviparous fishes. Comp. Biochem. Physiol., 59A: 165-168.

Gasco, L., Zoccarato, I., Lussiana, C. and Amaral, H. Jr. 1999. Effect of dietary lipid source on semen fatty acids profile and sperm motility after cryopreservation in rainbow trout (Onchrhynchus mykiss ). Riv. Ital. Acqua., 34: 61-69.

Ghadially, F. N. 1986. Processing of tissue for routine electron microscopy. Course on diagnostic Electron Microscopy. Jaslok Hospital and Research Center, Mumbai, p. 1-7.

Gopalakrishnan, K., Hinduja, I. N., Mehta, R. H. and Kumar, T. C. A. 1991. Assessment of mitochondrial activity of human spermatozoa: motility/viability in fertile/ infertile men. Mol. Androl., 3: 243-250.

Gopalakrishnan, K., Hinduja, I. N., Mehta, R. H. and Kumar, T. C. A. 1998. Laboratory manual for human semen analysis. Institute for Research in Reproduction and WHO Collaborating Center, Mumbai, 34 pp.

Gupta, S. D. and Rath, S. C. 1993. Cryogenic preservation of carp milt and its utilisation in seed production. In: Joseph, M. M. and Mohan, C. V. (Eds.), The Third Indian Fisheries Forum Proceedings. Asian Fisheries Society Indian Branch, Mangalore, p. 77-79.

Hajirezaee, S. and Rafiee, G. R. 2010. Stress responses of Persian sturgeon, Acipenser persicus to repetition of a management stressor (handstripping of milt). J. Appl. Biol. Sci., 4: 9-12.

He, S. and Woods III, L. S. 2004. Changes in motility, ultrastructure, and fertilization capacity of striped bass Morone saxatilis spermatozoa following cryopreservation, Aquaculture, 236: 677-686.
Izquierdo, M. S., Fernandez-Palacios, H. and Tacon, A. G. J. 2001. Effect of broodstock nutrition on reproductive performance of fish. Aquaculture, 197: 25-42.

Jamieson, B. G. M. 1991. Fish evolution and systematic: Evidence from spermatozoa. Cambridge University Press, Cambridge, $319 \mathrm{pp}$.

Kristian, J., Hatef, A., Alavi, S. M. H. and Policar, T. 2014. Sperm morphology, ultrastructure and motility in pike perch Sander lucioperca (Percidae, Teleostei) associated with various activation media. Czech J. Anim. Sci., 59: 1-10.

Kruger, J. C. De, W., Smit, G. L., Vuren, J. H. J. V. and Ferreira, J. T. 1984. Some chemical and physical characteristics of the semen of Cyprinus carpio L. and Oreochromis mossambicus (Peters ). J. Fish Biol., 24: 263-272.

Lahnsteiner, F., Berger, B., Weismann, T. and Patzner, R. 1996. Changes in morphology, metabolism and fertilization capacity of rainbow trout semen following cryopreservation, Progress. Fish Cult., 58: 149-159.

Lahnsteiner, F., Patzner, R. A. and Weismann, T. 1994. The testicular main ducts and the spermatic ducts in some cyprinid fishes-II: Composition of the seminal fluid. J. Fish Biol., 44: 459- 467.

Lahnsteiner, F., Weismann, T. and Patzner, R. A. 1992. Fine structural changes in spermatozoa of the grayling, Thymallus thymallus (Pisces : Teleostei), during routine cryopreservation. Aquaculture, 103: 73-84.

Lahnsteiner, F., Weismann, T. and Patzner, R. 1997. Methanol as cryoprotectant and the suitability of $1.2 \mathrm{ml}$ and $5 \mathrm{ml}$ straws for cryopreservation of semen from salmonid fishes. Aquac. Res., 28: 471-479.

Nelson-Somogyi 1945. Estimation of the total reducing sugars. In: Oser, B. L. (Ed.), Hawk's physiological chemistry. 14 edn., McGraw Hill Publishers, New York, p. 1054-1055.

Ogale, S. N. 1994. Endangered Deccan mahseer, Tor khudree (Sykes) - A case study. In: Dehadrai, P. V., Das, P. and Verma, S. R. (Eds.), Threatened fishes of India. Nature Conservators, Muzaffarnagar, p. 213-218.

Patil, R. and Lakra, W. S. 2005. Effect of different cryoprotectants, equilibration periods and freezing rates during cryopreservation of spermatozoa of mahseer, Tor khudree (Sykes) and T. putitora (Hamilton). Aquac. Res., 36: 1465-1472.

Plouidy, M. G. and Billard, R. 1982. The chemical composition of the companion fluids of the gametes in the common carp. In: Richter, C. J. J. and Goos, H. J. Th. (Eds.), Reproductive physiology of fish, PUDOC, Wageningen, $134 \mathrm{pp}$.

Rakitin, A., Ferguson, M. M. and Trippel, E. A. 1999. Spermatocrit and spermatozoa density in Atlantic cod (Gadus morhua): correlation and variation during the spawning season. Aquaculture, 170: 349-358. 
Ravinder, K., Nasaruddin, K., Majumdar, K. C. and Shivaji, S. 1997. Computerised analysis of motility, motility patterns and motility parameters of spermatozoa of carp following short-term storage of semen. J. Fish Biol., 50: 1309-1328.

Rurangwa, E., Kime, D. E., Ollevier, F. and Nash, J. P. 2004. The measurement of sperm motility and factors affecting sperm quality in cultured fish. Aquaculture, 234: 1-28.
Saad, A., Billard, R., Theron, M. C. and Hollebecq, M. G. 1988. Short- term preservation of carp (Cyprinus carpio) semen. Aquaculture, 71: 133-150.

Stasiak, A. S. and Baumann, C. P. 1996. Neutrophil activity as a potential bioindicator for contaminant analysis. Fish Shellfish Immunol., 6: 537-539.

Wei-Xin, Z. and Ren-Liang, J. 1991. Freezing damage to sperm and embryos of carp. Asian Fish. Sci., 4: 630-635.

Date of Receipt $\quad$ : 24.09 .2015

Date of Acceptance ： 25.12 .2015 